\title{
Sepaktakraw Smash Training Model Based on Training Aids Tool
}

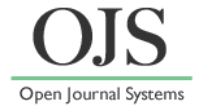

\author{
Wiwik Yunitaningrum ${ }^{1 *}$, Achmad Sofyan Hanif², Yusmawati², \\ Firmansyah Dlis ${ }^{2}$ \\ ${ }^{1}$ Tanjungpura University, Pontianak, Indonesia \\ ${ }^{2}$ Jakarta State University, Jakarta, Indonesia \\ *Email: wiwik.yunitaningrum@fkip.untan.ac.id
}

DOI: https://doi.org/10.33369/pendipa.4.2.6-13

\begin{abstract}
The aim of this study was to develop a sepaktakraw smash training model based on smash training aids. This research was based on a needs analysis with a survey method later according to the references and characteristics by looking at the analysis results of smash skill needs analysis model development based on media tools in the Pontianak city athletes packaged in print media products, namely a training model book. This research uses a development research method that refers to the of Borg and Gall development stages, using Pontianak athletes sample, amounting to 40 people aged 12-17 years and included in the adolescents category. Based on needs analysis data obtained $100 \%$ of athletes need the development of a sepak takraw smash training model in Pontianak city athletes based on training aids and analysis by experts developing a sepaktakraw smash training model based on training aids in Pontianak city athletes was feasible so that it can be used in the first stage of group testing limited (stage 3 trials) totaling 20 athletes and field trials in stage 4 totaling 40 concluded that the exercise model was valid so that athletes and trainers could use it during training. Whereas the effectiveness test obtained t-count $\geq t$-table (2.212.028 from the calculation results shows that there was a difference between the groups treated with the smash training model material that has been validated by experts (experimental group) experiencing progress results better training compared with a group that implement this type of training of trainers (control group) conclusion from these results was a model of skill training smash sepaktakraw-based tools drills smash in adolescent athletes Pontianak decent used as a medium for training in adolescent athletes.
\end{abstract}

Keywords: Exercise model, sepaktakraw smash, training aids.

\section{INTRODUCTION}

Sepak takraw is a sport that is already familiar to the public, but is not yet popular in Indonesian. Sepaktakraw has been developing since the 1970s until now both in terms of game rules and regulations as well as pe number the comparison

Achievement of the best achievements must start from good and right practice. Training that is based on existing training principles and is carried out in a correct and creative way, will help to produce skilled and mature soccer takraw athletes. Point of a good takraw practice starts with family, community, sports teachers and the takraw sports club.

The importance of the training process in supporting sports achievements is an important variable in coaching athletes. Exercises must be designed and developed properly and scientifically. In addition, it must be designed and developed as creatively as possible to increase the effectiveness, efficiency and attractiveness of training. The training purpose itself is to make skilled athletes perform various techniques needed in the sepaktakraw.

Sepak takraw sports have very specific characteristics compared to other sports, its contain acrobatic elements. Where in this sports game there are 3 players who have their respective duties and roles, namely server or so-called tekong, right wedge and left wedge which has a role as a feeder or smasher.

Sepak takraw's skill includes the subject on the head, feet to play it and keep the ball from falling to the floor, by placing the ball on the target, this game resembles a volleyball game. (Maseleno, 2014: 1). 
Sepaktakraw game can be said as one of the sports that has a very high complexity in the movement technique which contains acrobatic elements that demand high movement skills where in this sport playing the ball with one foot and the ball must not fall to the floor the game is done with a few touches namely head, legs and shoulders can only be done alternately and only 3 times the opportunity in each team in the game means that this sport must have a high level of balance and coordination of movement.

Empirical data in the field shows that there are still obstacles in carrying out the exercise, especially smash technique. The first obstacle that is related to variations in the training model, the training model used today is still based on previous training experiences that are the main reference of the trainer in providing training material. This is not wrong, but with creativity and collaboration with academics, it will be possible to develop more varied practice forms. The second obstacle is the limited tools to practice smash skills. Because it is a complex and high-risk skill. At present, the trainer uses peching bad to carry out the smash technique, and only uses a training model with a throw ball. Basically,skills smash will be mastered well through gradual training. Training that starts from the lowest level to the highest level. The tools currently available can only be used for one form of training that functions only on the hitting accuracy the ball and is still limited in managing the difficulty level. The current model has not been able to meet the needs of the trainer in regulating the level of training.

The smash training tools or media presence during the training activities has a vital role, during the process by presenting the media as an intermediary able to help athletes focus more on practicing certain techniques. The training media can function as a tool for enhancing and adding functions during the training activities to accelerate the mastering techniques or skills.

Tool modification, proven to be able to increase the interest in sports activities, so that sports participation becomes higher, this is like what Sanz did when modifying tennis training equipment for beginner tennis athletes Sanz (2017: 8-9). Beginners in tennis, show more interest in the tennis game when practicing using a modified tool that is combined with the game. In volleyball, Smith \& Randall has also done equipment modification designed to promote skill acquisition, equipment innovation, and assessment of Smith \& Randall skill acquisition (Smith \& Randall, 1994). (Buszard et al., 2017) in their research stated that, studies consistently provide positive results for children playing tennis with modified equipment. Besides that, several tools / media modifications have also been carried out to improve motor performance to the mastery of skills (Moenig: 2015).

In sepak takraw practice, especially smash technique the training aid commonly used is the pole to hang the ball. The pole can also be set high and low. The tool is currently a major tool in helping the technique process of sepak takraw training smash. However, smash training aids can be developed further to enrich the variation of training smash model.

Based on field observations obtained information data obtained by researchers intending to develop a smash training model using training aids and see the impact of the improvement of the model on the ability of smashes in adolescent athletes.

The formulation of the problem based on the background described above as follows:

1. How to develop aexercise smash model in sepak takraw based on training aids for teen athletes

2. Effectiveness of sepak takraw smash model aexercise based on training aids for teen athletes

Based on James Tangkudung, (2016: 7), "Research based on field needs analysis studies and field studies that produce new products or develop existing products." Conny Semiawan, (2007: 181) states "Limiting the difference between research and implementation in education between qualitative and quantitative ".

From some expert opinions it can be concluded that research development is an attempt to produce an update a product form. preliminary research studies in data collection as a basis for compiling needs analyzes. This research resulted in a renewal in the of sepak takraw smash training model development based on training aids for athletes aged 12-16 years.

According to Borg \& Gall, (1983: 772), explained that the development research model is "research using a process of developing and validating educational products". This research is also called "research-based development", 
with the ultimate goal being efforts to improve education quality ultimately produces a strategy in order to improve the quality of Education. According to Kemp in Trianto, (2007: 62) development that uses a continuum circle pattern, where each stage there is improvement. The development model in this study uses the stages of the Borg and Gall model in the development of this model in a detailed phasing where active interaction is possible by implementing strategies and characteristics that involve the environment in the learning process.

The learning motion concept is a basis for the movement skills process implementation, the ability to move is very important in human activities with the ability to move people can do something in accordance with expectations. Motoric skills according to Widiastuti., (2011: 165) are the ability of a person to engage in physical activity to carry out a movement, while motoric ability is the ability to do a motion. Motion learning according to Schmit (2000) motion learning or motoric learning is motion learning in the form of relatively constant changes as a one's training and experience result. Fitt and Posner (2011) motion learning is divided into three distinct stages:cognitive stage, associative stage, and autonomicstage. These stages are determined by the tendency of a person's behavior to be displayed at various points.

Sepak takraw game is a sport that requires a high level of movement skills where the movements in sepak takraw are included in high complexity movements, in the game takraw needed motor skills to support the sepaktakraw game. Power, speed, flexibility, agility, and coordination are components of motor skills needed in playing takraw.

Lakshmikrishnan and Silvakumar, (2013: 152-153) training is a process scientifically based, organized, planned and systematic learning management (pedagogical) aimed at perfection and performance improvement in sports competitions. Exercise is the preparing process an athlete effort to achieve performance (appearance) and higher levels. Bompa and Haff, (2009: 2). Training is an effort or process in achieving higher performance in an organized, systematic, repetitive manner by paying attention to the intensity and load of training in an effective and efficient manner in accordance with the objectives to be achieved.
Adolescence is the Latin language "adolescere" which means development towards adulthood, the process towards adulthood Desmita., (2010). Monks, Knoers and, Haditono, (2006) division in the stages of adolescence, namely at the age of 12 years - 21 years. In Indonesia, the dolescents mass is divided into the stages of school level which are still at the junior high school, senior high school and university, adolescence in Indonesia at the age of 14 years - 24 years, which are used as subjects in this study are age 12-17 years

Sepak takraw is a worldwide sport that is popular in southeast asia in the Malay language of soccer and takraw has the same meaning of kicking, Sepak takraw comes from the Malay language while takraw is Thai. (Kubo at all 2016: 986). Sepak takraw game called soccer which comes from the South Sulawesi precisely in Makassar. Hanif, (2015: 11). Sepak takraw is a game full of acrobatic elements, played by two separate teams (Nizam, K. \& Sugiyanto, 2018: 156). Sepak takraw is a game played by 2 teams consisting of 3 people who have their respective functions and tasks and are full of acrobatic elements. The game is for the whole body except for the hand.

Smash the ball towards your opponent is a series of final moves in the form of attacks in the game that can produce numbers failure Smash means the loss of opportunity to get numbers and opportunities for opponents to add numbers, otherwise the success of smesh will produce points for the Dervish attack team (1992: 66). According to Hanif, (2015: 49) Smash is a series of movements consisting of prefix, repulsion, body position in the air. There are 2 types of smash in the game sepaktakraw ie smash roll and smash straight.

Smash straight is a smash that was done by position of the body back to the net, while doing the prefix and the foot repulsion that is used as a pedestal removed beforehand, the motion explosively in which the foot is used when refuse is leg swinging after foot down do swing leg with perkenaan the ball on the instep and make a landing motion using the foot used when repulsion first followed by a swinging foot (Hanif, 2015: 36)

Pellett \& Lox (1998: 453) states that in addition to the potential for improved performance, modifications in sports equipment must also be linked to increased selfefficacy (defined as a specific situation or form of self-confidence). 
In the realm of physical education, Metzler, (2011) states that modifications to equipment, space, and regulations to give teachers ideas about how to increase or decrease the level of challenge or complexity to better suit students abilities. According to Thrope in Olivares, Jaime, López, Luis., Calderón (2016: 208) in the pedagogical principle of modification becomes a key element of the game, although the essence and rules remain the same, the aim is to open up the possibility of exploring tactical sports problems or questionable sports categories.

Smash aids modification in this study is to use a tool to hang a takraw ball that can be assembled (can be broken down into several metal units that can be reassembled), can be used for a single ball hanger, the ball is hung by a rope tied around a rope the end of the pole on a tool made of iron whose height can be lowered and stretched using a rope in accordance with the height with the range, and can be used to hang 5 balls if the tool is combined as needed during the exercise.

The development of the model in this research is the exercise model smash the varied takraw socceruses smash training aids, which have been adapted to the athlete's physiological, anatomical, and motoric characteristics.

In the end, the development smash practice model with sepaktakraw exercise tools printed books and packages include tools workout interesting modifications.

\section{RESEARCH METHODS}

Retrieval of data in the sepaktakraw field on the Tabrani ahmad street Pontianak, West Kalimantan, The research subjects were male athletes of PSTI Pontianak city. Conducted in February 2019 - September 2019, this research uses the following stages of model development research: (1) Preliminary Research, (2) Model development planning, (3) Expert validation and model revision, (3) Group testing small, (4) Product revision (5) Large group trial, (6) Product revision II, (7) Model implementation, (8) Effectiveness and revision testing, (8) Product results

The development of this sepak takraw smash exercise model is the development in the forms of thetraining model smash sepaktakraw, in the form of the development of the prefix movement, the core movement and the final movement consisting of 34 training materials. This study subjects were teenage athletes.
From the description above, the development of the sepaktakraw using smash training aids was compiled and developed in the variations of sepak takraw training model using smash training aids.

Research into the exercise development sepak takraw model smash based on these training aids uses by using Research and Development from Borg and Gall (1883: 775 ) with the following stages:

1. Conducting preliminary research (2) Conducting planning (3) Developing initial product forms (4) Conducting preliminary field tests (5) pruduk revisions (6) main field trials (with 30-100 subjects). (7) product revisions (based on suggestions and results of key field trials). (8) Field tests with 40-200 subjects (9) Final product revision (10) Making a report on the product in a journal, working with publishers who can distribute commercially.

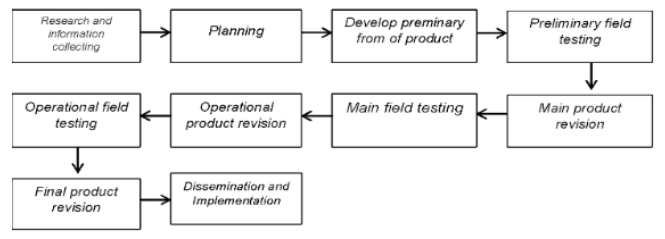

Figure 1. Borg and Gall Research and Development

This study uses stages that have been adjusted to the situation and conditions in the field by making various modifications related to the sepaktakraw smash training model in accordance with the desired goals.

The instrument used are test and non-test instruments. The test instrument used was the motion skills test instrument smash (developed by previous researchers will be validated by a measurement test expert), a smash assessment test instrument to determine the effectiveness of the developed model.

The non-test instrument used was an instrument in the form of a questionnaire in the form of a needs analysis, as a reference in analyzing how important the development of this training model was for athletes and trainers.

\section{RESULTS AND DISCUSSION}


The development of the sepak takraw smash exercise model based on training aids contains 8 smash materials, namely (1) Exercise prefix / smash steps, (2) Leap motion, (3) Blow accuracy training exercises, (4) Model hanging ball smash training (fixed hanging ball), (5) smash training with variations in ball position area (loose hanging ball), (6) smash training model with variations in position and target area (loose hanging ball), (7) smash training model with variations in height of the ball (hanged off with a target) (8) Smash training with toss.

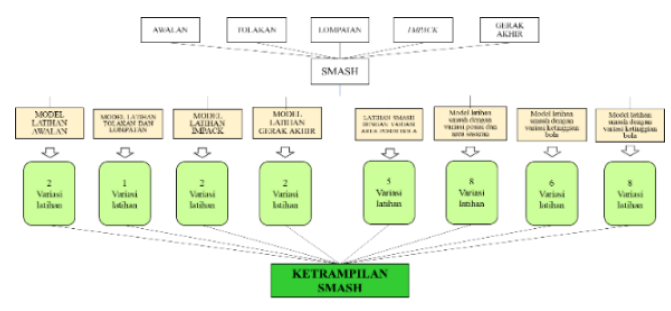

Figure 2. Smash Exercise Model Design

The analysis results of sepak takraw smash training model by experts are variations of the smash training model based on training aids as a whole are feasible to use. The material amount that was originally 35 to 34 training materials are feasible and can be given or applied to athletes during training.

In the initial trial phase, the overall learning model smash based on training aids can be applied because the subjects are able to do the training model. From the observations in the field and input and suggestions, a revision I was made, a revision I as a basis for product development, then a stage I trial consisting of 20 subjects, from the results of a phase I trial, the subjects were able to practice the model well, the basis for observing the first phase trial used as material for phase II revision for product improvement, then a phase II trial was conducted with a total of 40 athlete subjects, based on observations made for phase II revision, a draft of the sepaktakraw smash training model based on training aids can be implemented well. So that the training model is appropriate to be used in the process of smash training in Pontianak city youth athletes. The next step is to test the effectiveness to find out how much the improvement in applying the training model to the smash skills of the athlete. The effectiveness test was carried out on sepaktakraw athletes totaling 20 athletes for the control group or comparison group with the usual training material provided by the trainer, and 20 for the experiment by applying the sepaktakraw smash training model based on training aids.

The effectiveness test results carried out with several stages data analysis as follows:

a. Analysis test

1. Normality tests

Tests for normality of data from variables are carried out using thetest lilliefors.

Table 1. Test for the data normality

\begin{tabular}{|c|c|c|c|c|c|}
\hline No & Variabel & $\mathrm{n}$ & L0 & Ltabel & Distribution \\
\hline 1 & $\begin{array}{l}\text { Pretest in } \\
\text { Experimental } \\
\text { group }\end{array}$ & 20 & 0,0738 & 0,190 & Normal \\
\hline 2 & $\begin{array}{l}\text { Posttest in } \\
\text { Experimental } \\
\text { group }\end{array}$ & 20 & 0,1492 & 0,190 & Normal \\
\hline 3 & $\begin{array}{l}\text { Pretest in } \\
\text { control group }\end{array}$ & 20 & 0,0821 & 0,190 & Normal \\
\hline 4 & $\begin{array}{l}\text { Posttest in } \\
\text { control group }\end{array}$ & 20 & 0,1134 & 0,190 & Normal \\
\hline
\end{tabular}

Table 2. Test for the data homogeneity

\begin{tabular}{clcccc}
\hline No & Variabel & $\mathrm{n}$ & Fcount & $\begin{array}{l}\text { Ftab } \\
(5 \%)\end{array}$ & Distribution \\
\hline 1 & $\begin{array}{l}\text { Experimental } \\
\text { group }\end{array}$ & 20 & 2,08 & 2,15 & Homogen \\
\hline 2 & $\begin{array}{l}\text { Control } \\
\text { group }\end{array}$ & 20 & 1,73 & 2,15 & Homogen \\
\hline 3 & $\begin{array}{l}\text { Experiment } \\
\text { and control } \\
\text { group }\end{array}$ & 20 & 0,88 & 2,15 & Homogen \\
\hline
\end{tabular}

b. T test of Dependent Samples and Independent Samples (Paired t-test)

The normality tests results show nominal distribution of data and homogeneity tests also show homogeneous data afterwards carried out parametical tests using Paired Two Samples for Means for each group then a different test is performed by parametric comparison testing using t-Test: Two-Sample Assuming Equal Variances. As follows:

1. Dependent $T$ Test Sample Initial Test and Final Test Experiment Group 
Table 3. Test Results Dependent Sample Initial Test and Final Experiment Group

\begin{tabular}{cccccc}
\hline \multicolumn{2}{c}{ Mean } & $\mathrm{n}$ & Tcount & $\begin{array}{c}\text { Ftabel } \\
(\mathrm{a}=5 \%)\end{array}$ & Conclusion \\
\cline { 1 - 5 } Pretest & Posttest & & & & \\
\hline 50,15 & 59,52 & 20 & 9,67 & 2,101 & Signicant \\
\hline
\end{tabular}

2. T Test Dependent Sample Initial Test and Final Test Control Group

Based on the results of the analysis of the mean different test with the Dependent $T$ test Control group samples are obtained as follows:

Table 4. Summary of $T$ test Dependent Sample Initial Test and FinalControl Group

\begin{tabular}{cccccc}
\hline \multicolumn{2}{c}{ Mean } & $\mathrm{n}$ & Tcount & $\begin{array}{c}\text { Ftabel } \\
(\mathrm{a}=5 \%)\end{array}$ & Conclusion \\
\cline { 1 - 2 } Pretest & Posttest & & & \\
\hline 49,84 & 53,73 & 20 & 4,68 & 2,101 & Signicant \\
\hline
\end{tabular}

Independent Test Sample Final test group experiment and final test Control Group

Because the results of the homogeneity test variant Fcount is smaller than the Ftable then data has The same variant (equal variance) therefore tested the $\mathrm{T}$ (Test:Two-Sample Assuming Equal Variances) using the formula polled variance. Based on analysis of $\mathrm{T}$ test for variance equal to thepolled formula variancefor post test experimental group and post test the control group then obtained as follows:

Table 5. Summary of test results T Test: Two-Sample Assuming Equal Variancespost test andexperimental group posttest Control group

\begin{tabular}{clcccc}
\hline Mean & & n & T count & $\begin{array}{c}\text { Ftabel } \\
(\mathrm{a}=5 \%)\end{array}$ & Conclusion \\
\cline { 1 - 4 } $\begin{array}{c}\text { Pretest } \\
\text { experimental } \\
\text { group }\end{array}$ & $\begin{array}{l}\text { Post } \\
\text { test } \\
\text { control }\end{array}$ & & & & \\
\hline 59,52 & 53,73 & 20 & 2,21 & 2,028 & Signicant \\
\hline
\end{tabular}

After testing parametric comparison with t-Test: Two-Sample Assuming Equal
Variances it was found that there were differences between the smash skills test results in the experimental group and the smash skills test results in the Control group. To find out the increase in smash pregnancy using thetest gain score. Data on the gain score in the following table:

Table 6. Summary of Gain Score of Sepaktakraw Smash Skills in Experiments and Control Groups

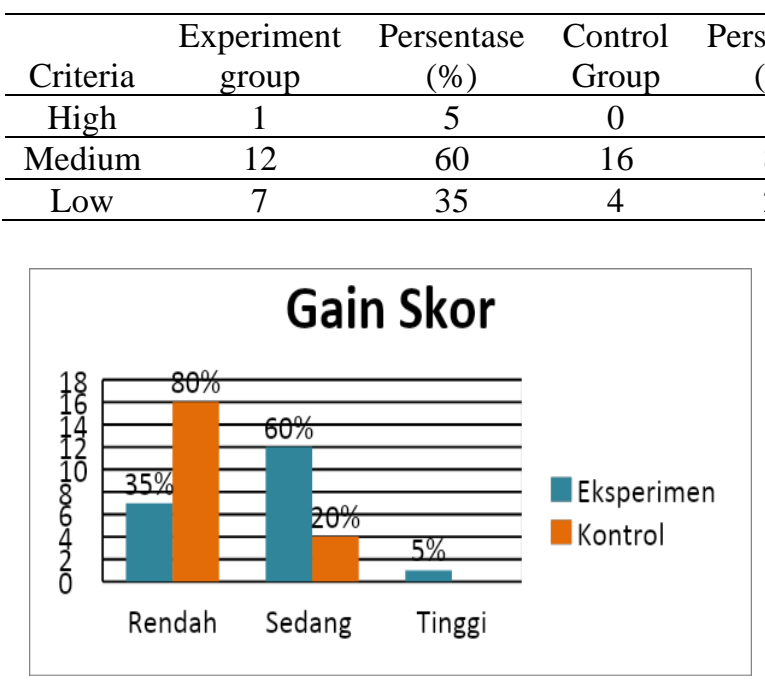

Figure 3. GainScores in Smash Skills Experiments and Control Groups.

From the calculation of the data above shows the experimental group smash skills that were treated with aexercise training smash sepaktakraw-basedtool in Pontianak city athletes better than the control group smash skills.

\section{CONCLUSION}

Based on the needs analysis description and field trials conducted on the application of the development of a model of sepaktakraw smash training based on training aids as follows:

1. Research produced development sepak takraw training smash model based on training tools that are appropriate and suitable for use by athletes and trainers in training process

2. Product development in sepak takraw training model smash based on smash training aids can improve the smash 
ability of Pontianak city sepaktakraw athletes and have been tested for effectiveness.

\section{REFERENCES}

Borg. W. R \& Gall, M. D. (1983). Borg. W. $R \&$ Gall, M. D.

Buszard, T., Reid, M., \& Farrow, D. (2017). Research inspired by Tennis Play and Stay: What have we learnt about equipment modification in tennis? ITF Coaching and Sport Science Review, 72(72), 5-7.

Conny Semiawan. (2007). NoCatatan Kecil Tentang Penelitian dan Pengembangan Ilmu Pengetahuan Title. Kencana Prenada Media Group.

Kosni, N. A., Abdullah, M. R., Juahir, H., Maliki, A. B. H. M., \& Musa, R. M. (2018). Establishing reliability of performance indicator of sepak takraw using notational.

Ball

Lakshmikrishnan, $\mathrm{R}$ dan Silvakumar, K. (2013). Effect Of Weight Training And Plyiometric Training On Strength Endurance And Leg Strength. 11, 1.

Maseleno, A. \& Hasan, M. M. (2014).

Metzler, M. W. (2011). Instructional models for physical education (3rd ed.). Holcomb Hathaway.

Moenig, U. (2015). Rule and equipment modification issues in World Taekwondo Federation ( WTF ) competition. Journal of Martial Arts Anthropology, 15(4), 3-12. https://doi.org/10.14589/ido.15.4.2

Mubin, A. S. A., Ahmad, N., Mamat, A., Taha, Z., \& Hasanudding, I. (2014). CDF study of drag and life of sepak takraw ball at different face orientations. Advances in Mechanical Eingineering.

Mylsidayu, A. \& Kurniawan, F. (2015a). Ilmu kepelatihan dasar. alfabeta.

Sanz, D. (2017). The importance of modifying the equipment for beginner tennis players: Tennis Play and Stay development in Spain. Coaching \& Sport Science Review, 72(72), 8-9.

Schmit, R.A, \& Wisberg, C.A. (2000). Motor Learning and Performance: A Problem Basic- Learning Approach. USA: Humans Kinetics.

Serra-Olivares, Jaime, García-López, Luis M., Calderón, Antonio. (2016). Game-Based Approaches, Pedagogical Principles and Tactical Constraints: Examining Games Modification. Journal of Teaching in Physical Education. 35 (3). 208-218

Setyosari, P. (2013). Metode Penelitian Pendidikan dan Pengembangan. Prenada Media Group.

Tangkudung, J. (2016). Macam-macam Metodologi Penelitian Uraian dan Contohnya. Lensa Media Pustaka Indonesia.

Widiastuti. (2011). Tes dan Pengukuran Olahraga. PT. Bumi Timur Jaya.

Bompa T.O and G. Gregory Haff. (2009). Periodization Theory and Methodology of Training Fifth Edition. Human Kinetics.

Desmita. (2010). Psikologi Perkembangan. PT. Remaja Rosdakarya.

F.J. Monks, A.M.P. Knoers, Siti Rahayu Haditono. (2006). Psikolog Perkembangan: Pengantar dalam Berbagai Bagiannya, Yogjakarta: Gajahmada UniversityPress.

Kubo, Y., Nakazato, K., Koyama, K., Tahara, Y., Funaki, A., \& Hiranuma, K. (2016). The realition between hamstring strain injury and physical characteristics of japanese collegiate sepak takraw player. International of Journal Sports Medicine., 37.

Hanif, ahmad sofyan. (2015). Sepaktakraw Untuk Pelajar. raja grafindo persada. 
Saputro, D. B., \& Supriyadi. (2017). Pengembangan variasi latihan sepak sila sepak takraw untuk tingkat pemula. Indonesia Performance Journal. Universitas Negeri Malang. No. 112-118.

Ratinus Darwis dan Dt. Penghulu Basa. (1992). Olah Raga Pilihan Sepak Takraw. Jakarta: Depdikbud.

Nizam, K. \& Sugiyanto, F. (2018). The influence of ball modification on sepak takraw service learning outcome. Advances in Social Science, Education and Humanities Research.
Pellett, T. L., \& Lox, C. L. (1998). Tennis racket head-size comparisons and their effect on beginning college players' achievement and self-efficacy. Journal of Teaching in Physical Education, 17(4), 453-467. https://doi.org/10.1123/jtpe.17.4.453

Serra-Olivares, Jaime, García-López, Luis M., Calderón, Antonio. (2016). Game-Based Approaches, Pedagogical Principles and Tactical Constraints: Examining Games Modification. Journal of Teaching in Physical Education. 35 (3). 208-218 Sugiyono., 2015. Metode Penelitian dan Pengembangan (Research and Development). Bandung: Alfabeta. 